\title{
Correction to: Default analysis in mortgage risk with conventional and deep machine learning focusing on 2008-2009
}

\section{Vikram Ojha ${ }^{1} \cdot$ JeongHoe Lee ${ }^{1}$ (D)}

Accepted: 3 August 2021 / Published online: 12 August 2021

(C) The Author(s), under exclusive licence to Springer Nature Switzerland AG 2021

\section{Correction to: Digital Finance https://doi.org/10.1007/s42521-021-00036-4}

Figure 7 in the original version of this article was corrupted and has been replaced.

In table 2 the total number of "All loans (2005-2009)" must read 1430,982 instead of 143,982 .

The number has been corrected in the original version of this article.

Table 2 Loan data universe

\begin{tabular}{lcccr}
\hline & Total loans & Non-default & Default & \%Default \\
\hline All loans (2005-09) & 1430,982 & 1340,313 & 90,669 & $6.34 \%$ \\
Subprime loans (2005-09) & 200,959 & 170,210 & 30,749 & $15.30 \%$ \\
\hline
\end{tabular}

Publisher's Note Springer Nature remains neutral with regard to jurisdictional claims in published maps and institutional affiliations.

The original article can be found online at https://doi.org/10.1007/s42521-021-00036-4.

\section{JeongHoe Lee}

familylandjp@yahoo.co.jp

1 Standard \& Poor's (S\&P Global Ratings), 55 Water Street, New York, NY 10041, USA 